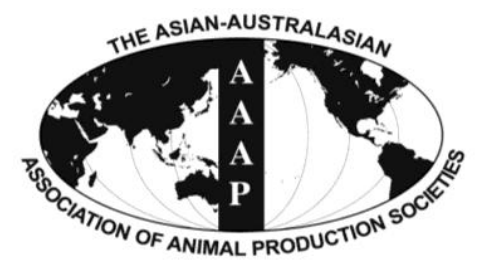

Asian-Aust. J. Anim. Sci.

Vol. 25, No. 5 : 653 - 658

May 2012

www.ajas.info

http://dx.doi.org/10.5713/ajas.2012.12020

\title{
Effects of Dietary Potential Acid Production Value on Productivity in Dairy Cows
}

\author{
E. T. Kim, S. S. Lee ${ }^{1}$, H. J. Kim ${ }^{2}$, J. Y. Song ${ }^{2}$, C.-H. Kim ${ }^{3}$ and Jong K. Ha ${ }^{2}$ * \\ Division of Applied Life Science (BK21 program), IALS \\ Graduate School of Gyeongsang National University, Jinju, 660-701, Korea
}

\begin{abstract}
This study was conducted to estimate the potential acid production value (PAPV) of major diets and to determine the relationship between dietary PAPV and dairy production traits. Estimation of PAPV of major cattle feeds was based on an in vitro technique, which determined the degree of $\mathrm{Ca}$ dissociation from $\mathrm{CaCO}_{3}$. Data on feeds and production traits were collected on 744 multiparous lactating Holstein dairy cows from five different farms. Grains had high PAPV with variable protein sources and by-products. High PAPV feedstuffs had a higher total gas production and lower $\mathrm{pH}$ compared to those with low PAPV. Dietary PAPV had a positive correlation with intake of dry matter, NDF, ADF, milk yield and milk solid production but a negative correlation with milk protein and milk fat concentration. Current results indicate that dietary PAPV can be utilized in predicting dairy production traits. (Key Words: Potential Acid Production Value (PAPV), TMR, Metabolic Disease, Ruminal Fermentation, Milk Yield, Dairy Cow)
\end{abstract}

\section{INTRODUCTION}

The high productivity of modern dairy farming requires excessive feeding of commercial concentrates and grains. However, the intake of large amounts of high energy feeds could decrease ruminal $\mathrm{pH}$ and disturb stable ruminal fermentation as grain contains easily fermentable carbohydrates (Dunlup, 1972; Russell et al., 2001; Choi et al., 2003). In addition, the type of concentrate is a determining factor for the occurrence of abnormal ruminal fermentation. Physically effective fiber is the fraction of feedstuffs that stimulates saliva secretion by chewing activity. The balance between the production of fermentation acid and bicarbonate and phosphate buffers in saliva neutralize acids and plays an important role in the

\footnotetext{
* Corresponding Author: Jong K. Ha. Tel: +82-2-880-4809, Fax: +82-2-875-8710, E-mail: jongha@snu.ac.kr

${ }^{1}$ Division of Applied Life Science (BK21 Program), IALS, Graduate School of Gyeongsang National University, Jinju 660701, Korea.

2 Department of Agricultural Biotechnology and Research Institute for Agriculture and Life Sciences, College of Agriculture and Life Sciences, Seoul National University, Seoul 151-742, Korea.

${ }^{3}$ School of Animal Life and Environment Science, Hankyong National University, Anseong, 456-749, Korea.

Submitted Jan. 10, 2012; Accepted Feb. 16, 2012; Revised Feb. 21, 2012
}

regulation of ruminal $\mathrm{pH}$. Allen (1997) indicated that low ruminal $\mathrm{pH}$ led to a decreased DMI, fiber digestibility and microbial yield and thus a reduction of milk production and increased feed costs. Diets should be formulated to maintain optimal ruminal $\mathrm{pH}$, and ruminal $\mathrm{pH}$ should have minimal variation due to feeding management. Previous studies suggested that ruminal $\mathrm{pH}$ correlates closely with ruminal motility (Ash, 1959), microbial yield (Oliveira et al., 1997), methane production (Lee et al., 2003), dry matter intake (Dewhurst et al., 2001), milk yield (Wadhwa et al., 2001b) and fiber digestion (Smith et al., 1973; Fondevilla et al., 1994). Low ruminal $\mathrm{pH}$ has direct and negative effects on energy intake and absorption of protein, which is a primary factor limiting production of high producing dairy cows. Therefore, maintaining an optimal ruminal $\mathrm{pH}$ is essential for higher productivity, and estimation of acid production capability of feedstuffs is important in diet design to avoid excess acid accumulation in the rumen. Precise estimation of the potential acid production value of individual feedstuffs and mixed feeds would be optimal; however, it is not an easy task. In addition to traditional indicators of acid production values such as $\mathrm{pH}$ and lactic acid, acidogenicity based on $\mathrm{Ca}$ release after rumen incubation has been proposed as an alternative method (Wadhwa et al., 2001a). Various factors that might affect acidogenicity, which is noted as potential acid production value (PAPV), have been 
discussed previously (Song, 2005).

The objectives of this study were to measure the PAPVs of the major ingredients fed to dairy cows and to assess the relationships between PAPV and performance parameters of lactating cows under practical farm conditions.

\section{MATERIALS AND METHODS}

\section{Experiment 1: Estimation of PAPV of major feedstuffs}

Animal: A fistulated Holstein cow of $500 \mathrm{~kg}$ body weight was used as a donor of rumen fluid. Tall fescue and commercial concentrate (Purina ${ }^{\circledR}$ : crude-protein content, $12 \%$ ) in the ratio of 3 to 2 were fed at $2 \%$ of body weight twice a day. Water and mineral-vitamin block were allowed ad libitum.

Rumen fluid: The rumen fluid was collected from the fistulated Holstein cow before morning feeding. Rumen samples were collected in a bottle, previously kept warm and filled with $\mathrm{O}_{2}$ free- $\mathrm{CO}_{2}$ gas, carried to the laboratory, and filtered through four layers of cheesecloth before mixing with buffer maintained at $39^{\circ} \mathrm{C}$ and under $\mathrm{O}_{2}$-free $\mathrm{CO}_{2}$ gas.

Feedstuffs: Feed ingredients were freeze-dried and ground through a 1-mm screen on a laboratory mill before being returned to the freeze-drier to remove any moisture produced during grinding. The buffer described by Wadhwa et al. (2001a, Table 1) was used as a medium. Cysteine hydrochloride monohydrate $(0.025 \% \mathrm{wt} / \mathrm{vol})$ was added just prior to incubation. One-gram (DM) samples were weighed directly from the freeze-drier (with samples held in a desiccator) and were incubated with $30 \mathrm{ml}$ of buffered rumen sample comprised of $60 \%$ buffer and $40 \%$ rumen fluid. The bottles were sealed with butyl rubber stoppers and aluminum seals (Wheaton Scientific). The incubations were carried out in $60 \mathrm{ml}$ serum bottles held in an incubator at $39^{\circ} \mathrm{C}$ for $24 \mathrm{~h}$.

PAPV determination of feedstuffs: PAPV determination was based on in vitro incubation of concentrates with buffered rumen fluid. Ruminal acid production, which was the residual acidity after fermentation of concentrates, was evaluated by assessing the amount of $\mathrm{Ca}$ dissociated from insoluble $\mathrm{CaCO}_{3}$ powder (Sigma Chemical Co., St. Louis, MO, USA). Contents $(2 \mathrm{ml})$ were withdrawn from each

Table 1. Composition $(\mathrm{g} / \mathrm{L})$ of the buffer used for determination of dietary potential acid production value

\begin{tabular}{lc}
\hline & Concentration \\
\hline $\mathrm{NaHPO}_{3}$ & 5.880 \\
$\mathrm{Na}_{2} \mathrm{HPO}_{4}$ & 5.580 \\
$\mathrm{NaCl}$ & 0.282 \\
$\mathrm{KCl}$ & 0.342 \\
$\mathrm{CaCl}_{2} \cdot 2 \mathrm{H}_{2} \mathrm{O}$ & 0.028 \\
$\mathrm{MgCl}_{2}$ & 0.036 \\
\hline
\end{tabular}

tube after $24 \mathrm{~h}$ incubation and transferred to $2 \mathrm{ml}$ tubes containing $50 \mathrm{mg}$ of $\mathrm{CaCO}_{3}$ powder (Sigma Chemical Co., St. Louis, MO, USA). The mixture was shaken manually for $5 \mathrm{~s}$ and then centrifuged at 10,000 rpm for $20 \mathrm{~min}$ before analysis of $\mathrm{Ca}$ content in the supernatant with a $\mathrm{Ca}$ reagent working solution (Table 2) that contained calcium buffer and calcium binding reagent. Control (without $\mathrm{CaCO}_{3}$ powder) and blanks (with no feed sample) were included in each run. Absorbance values of all tubes was measured using a Shimadzu ${ }^{\circledR}$ UV 1601 spectrophotometer at $575 \mathrm{~nm}$ within three minutes after the addition of the sample. PAPV was calculated by the following equation: Dietary PAPV $(\mathrm{mg} \mathrm{Ca} / \mathrm{g}$ feed DM $)=$ treatment PAPV-control PAPV-blank PAPV.

Gas production: A detachable pressure transducer and a digital readout voltmeter (Laurel Electronics, Inc., CA, USA) were used to measure the headspace gas pressure of fermenting cultures. For total gas production measurement, the transducer was modified in such a way that it could be linked to the inlet of a disposable Luer-lock three-way stopcock (Theodorou et al., 1994). Bottles were warmed to $39^{\circ} \mathrm{C}$, and the headspace gas pressure in each tube was adjusted to ambient pressure prior to and just after inoculation with the microbial suspension. Gas pressure in the headspace was read from the display unit after insertion of the hypodermic syringe needle through the butyl rubber stopper above the culture medium.

\section{Experiment 2: Relationship between dietary PAPV and dairy performance}

Experimental animals and diets: A total of 744 multiparous lactating Holstein cows (average BW $630 \mathrm{~kg}$ ) from five different dairy farms were used to collect data on intake, feed composition and performance. The average performance of cows is shown in Table 4, and the average composition of feed ingredients is presented in Table 5.

Analysis of feeds and milk samples: Estimation of feed PAPV was conducted with the data obtained in experiment 1 and those previously determined in our laboratory. Feed samples were collected once a week for wet chemistry

Table 2. Compositions of the calcium buffer and calcium binding reagent used for determination of dietary potential acid production value

\begin{tabular}{lc}
\hline & Concentration $(/ \mathrm{L})$ \\
\hline Calcium buffer* & \\
Diethanolamine & $48.5 \mathrm{ml}$ \\
$\mathrm{MgCl}_{2}$ & $50.0 \mathrm{mg}$ \\
Sodium azide & $100.0 \mathrm{mg}$ \\
Calcium binding reagent & \\
O-cresolphtallein complexone & $0.0401 \mathrm{~g}$ \\
8-hydroxiquinolein & $2.4684 \mathrm{~g}$ \\
\hline pH 10.7.
\end{tabular}


analysis and production data calculations. Chemical compositions (dry matter, crude protein and ether extract) of feeds were analyzed using the method of AOAC (1990). ADF, NDF and ADL were analyzed using the methods of Van Soest and Robertson (1985) and Van Soest (1991). A Cornell Net Carbohydrate and Protein System (CNCPS) was used for fractionation of carbohydrate and protein in diets. Milk production and nutrient intake were recorded every week in the dairy farm. Samples were collected to analyze the composition and yield of milk every ten days. Milk samples were collected twice a day at 6:00 and 18:00 for the analysis of milk composition (fat, protein, lactose and milk urea nitrogen) using a Milkoscan 5000 (Foss Electric Co.). Morning and evening milk samples were pooled together in equal proportion and subjected to composition analysis.

\section{Statistical analysis}

Data were analyzed using the general linear model (GLM) procedure of the Statistical Analysis System Institute, Inc. (SAS, 1995). Differences among means were tested for significance using Duncan's multiple range test of SAS (1995). Pearson's correlation coefficients between dietary PAPV and lactating performance parameters were evaluated.

\section{RESULTS AND DISCUSSION}

\section{Experiment 1: Potential acid production value of major ingredients}

PAPV (mg Ca/g feed DM), $\mathrm{pH}$ and gas production by different feedstuffs after $24 \mathrm{~h}$ incubation are shown in Table 3. In general, feedstuffs having higher PAPV produced more total gas with lower $\mathrm{pH}$, as expected. The relationship between PAPV and total gas production or $\mathrm{pH}$ has been observed in a previous study (Song, 2005) with a similar trend. Of the tested feedstuffs, the grains and corn germ meal showed the highest PAPVs. There was a large variation in PAPV among oilseed meal samples. Corn germ meal and coconut meal were high in PAPV, while corn gluten meal, palm oil meal and rapeseed meal had lower PAPV. Bran and hull samples were also variable in PAPV. Protein sources, except corn germ meal, had a much lower PAPV than the starch feeds, which is similar to the results of Wadhwa et al. (2001a). The low PAPV of protein sources can be explained by higher buffer capacity of dietary proteins. For instance, Jasaitis et al. (1987) reported a high $\mathrm{pH}$ and buffering capacity of protein feeds due to the buffering ability of amino groups, and Crawford et al. (1983) also showed that a smaller amount of base was required to maintain the $\mathrm{pH}$ in a continuous culture system when high protein feedstuffs were used. Buffering in the rumen is mainly due to ammonia from dietary proteins with
Table 3. Potential acid production value ( $\mathrm{mg} \mathrm{Ca} / \mathrm{g}$ feed DM), gas production $(\mathrm{ml})$ and $\mathrm{pH}$ after $24 \mathrm{~h}$ incubation

\begin{tabular}{|c|c|c|c|}
\hline Ingredient & PAPV & $\begin{array}{c}\text { Gas } \\
\text { production }\end{array}$ & $\mathrm{pH}$ \\
\hline \multicolumn{4}{|l|}{ Grains } \\
\hline Corn & $32.94^{\mathrm{b}}$ & $92.47^{\mathrm{abc}}$ & $5.00^{\mathrm{i}}$ \\
\hline Corn flake & $38.68^{\mathrm{a}}$ & $86.57^{\mathrm{d}}$ & $4.86^{\mathrm{j}}$ \\
\hline Wheat-white & $39.92^{\mathrm{a}}$ & $93.86^{\mathrm{ab}}$ & $4.89^{j}$ \\
\hline \multicolumn{4}{|l|}{ Oilseed meals } \\
\hline Corn germ meal & $34.76^{\mathrm{b}}$ & $82.15^{\mathrm{e}}$ & $5.05^{\mathrm{i}}$ \\
\hline Corn gluten meal & $5.62^{\mathrm{ef}}$ & $54.64^{\mathrm{i}}$ & $6.03^{\mathrm{bc}}$ \\
\hline Coconut meal & $17.12^{\mathrm{d}}$ & $91.24^{\mathrm{abc}}$ & $5.33^{\mathrm{g}}$ \\
\hline Palm meal & $2.19^{\mathrm{f}}$ & $63.55^{\mathrm{h}}$ & $5.62^{\mathrm{d}}$ \\
\hline Rapeseed meal & $2.42^{\mathrm{f}}$ & $74.75^{\mathrm{f}}$ & $5.98^{\mathrm{c}}$ \\
\hline Soybean meal & $8.50^{\mathrm{e}}$ & $95.60^{\mathrm{a}}$ & $6.08^{\mathrm{b}}$ \\
\hline \multicolumn{4}{|l|}{ Bran and hulls } \\
\hline Beet pulp & $25.14^{\mathrm{c}}$ & $68.99^{\mathrm{g}}$ & $5.24^{\mathrm{h}}$ \\
\hline Corn gluten feed & $14.46^{\mathrm{d}}$ & $89.54^{\mathrm{bcd}}$ & $5.46^{\mathrm{ef}}$ \\
\hline Cottonseed hull & $5.23^{\mathrm{ef}}$ & $33.38^{\mathrm{j}}$ & $6.31^{\mathrm{a}}$ \\
\hline Rice bran & $13.9^{\mathrm{d}}$ & $81.38^{\mathrm{e}}$ & $5.43^{\mathrm{f}}$ \\
\hline Soybean hull & $5.37^{\mathrm{ef}}$ & $58.38^{\mathrm{i}}$ & $6.09^{\mathrm{b}}$ \\
\hline Wheat bran 1 & $7.99^{\mathrm{e}}$ & $88.31^{\mathrm{cd}}$ & $5.52^{\mathrm{e}}$ \\
\hline Wheat bran 2 & $14.57^{\mathrm{d}}$ & $86.56^{\mathrm{d}}$ & $5.34^{\mathrm{g}}$ \\
\hline
\end{tabular}

plant proteins providing between 10 and $20 \%$ of the total buffering capacity (Playne et al., 1966). Although differences in PAPV among various feed ingredients seemed to reflect the fermentable and buffering components of the feeds, the values may not be used as an absolute value for determination of acid production capability. This method was very sensitive to variation in microbial activity between batches of rumen fluid, which resulted in high variation in PAPV (data not shown). Standardization of rumen fluid and inclusion of reference feeds may reduce variation among incubation batches. Before a more reliable method for accurate estimation, PAPV can be useful in ranking of feeds, rather than using them as absolute values, when test feeds are evaluated in several runs. Therefore, PAPVs of total feeds from dairy farms were estimated to determine the relationship between dietary PAPV and production traits of dairy cows in a subsequent experiment.

\section{Experiment 2: Relationship between dietary PAPV and dairy performance}

Highly fermentable carbohydrates are often necessary to meet the energy requirements of high producing dairy cows. However, this practice may cause a reduced rumen $\mathrm{pH}$, low productivity and health problem like metabolic diseases. Generally, there is a close relationship among feeding, health and production; hence, metabolic disease like ruminal acidosis can be prevented by proper feeding 
Table 4. Average animal performance characteristics used for the in vivo experiment

\begin{tabular}{lrc}
\hline Item & & SE \\
\hline No. of animals & 744.00 & \\
Parity & 2.16 & 0.05 \\
Body weight $(\mathrm{kg})$ & 619.44 & 1.05 \\
Age (month) & 47.37 & 0.55 \\
Body condition score & 3.10 & 0.01 \\
Day in milk (d) & 195.15 & 5.11 \\
Days pregnant (d) & 89.57 & 2.46 \\
Milk yield $(\mathrm{kg} / \mathrm{d})$ & 31.32 & 0.35 \\
FCM (kg/d)* & 31.32 & 0.34 \\
Milk fat $(\%)$ & 4.07 & 0.02 \\
Milk protein $(\%)$ & 3.22 & 0.01 \\
Milk urea nitrogen $(\mathrm{mg} / \mathrm{dl})$ & 17.01 & 0.14 \\
Somatic cell count $(\times 1,000)$ & 159.17 & 10.50 \\
\hline
\end{tabular}

$* \mathrm{FCM}=4.0 \%$ fat corrected milk.

management. In this experiment, the PAPV (mg Ca/g feed DM) of TMR diets at five dairy farms was estimated based on values determined in the previous in vitro experiment, and the relationship between dietary PAPV and production traits was evaluated by Pearson's correlation. Field data were collected from 744 dairy cows, and the average performance is shown in Table 4, while the intake, dietary composition and nutrient concentration are presented in Table 5. Average body weight and milk yield in this in vivo experiment were approximately $620 \mathrm{~kg}$ and $31 \mathrm{~kg}$, respectively. Milk fat and protein were $4 \%$ and $3.2 \%$, respectively. As shown in Table 6, Pearson's correlations between PAPV and milk yield and FCM yield showed a positive correlation. Dietary PAPV also had a positive correlation with nutrient intake of dairy cows. However, PAPV was negatively correlated with milk fat and protein concentrations. From data obtained in the present study, it is apparent that cows receiving high PAPV consumed more
Table 5. Dietary composition and chemical composition of dairy herd feedstuffs for observation of dietary potential acid production value ( $\mathrm{mg} \mathrm{Ca} / \mathrm{g}$ feed $\mathrm{DM}$ ) vs performance relationship

\begin{tabular}{lrc}
\hline Composition & & SE \\
\hline Concentrate $(\mathrm{kg} / \mathrm{d})$ & 10.08 & 0.16 \\
Cotton $(\mathrm{kg} / \mathrm{d})$ & 2.45 & 0.01 \\
Tall fescue $(\mathrm{kg} / \mathrm{d})$ & 1.62 & 0.01 \\
Alfalfa hay $(\mathrm{kg} / \mathrm{d})$ & 2.09 & 0.02 \\
Rice straw $(\mathrm{kg} / \mathrm{d})$ & 1.40 & 0.01 \\
Beet pulp $(\mathrm{kg} / \mathrm{d})$ & 2.38 & 0.01 \\
Corn silage $(\mathrm{kg} / \mathrm{d})$ & 3.30 & 0.04 \\
Oats hay $(\mathrm{kg} / \mathrm{d})$ & 1.98 & 0.04 \\
Timothy $(\mathrm{kg} / \mathrm{d})$ & 2.37 & 0.03 \\
Dry matter $(\mathrm{kg} / \mathrm{d})$ & 24.42 & 0.13 \\
Net energy for lactation $(\mathrm{Mcal} / \mathrm{d})$ & 40.98 & 0.22 \\
Metabolizable protein $(\mathrm{Mcal} / \mathrm{d})$ & $2,471.78$ & 15.27 \\
Ether extract $(\mathrm{kg} / \mathrm{d})$ & 1.90 & 0.02 \\
Crude protein $(\mathrm{kg} / \mathrm{d})$ & 4.13 & 0.03 \\
NDFIP intake $(\mathrm{kg} / \mathrm{d})$ & 0.48 & 0.00 \\
ADFIP intake $(\mathrm{kg} / \mathrm{d})$ & 0.12 & 0.00 \\
RDP intake $(\mathrm{kg} / \mathrm{d})$ & 2.52 & 0.01 \\
NDF intake $(\mathrm{kg} / \mathrm{d})$ & 8.93 & 0.03 \\
Forage NDF intake $(\mathrm{kg} / \mathrm{d})$ & 3.33 & 0.06 \\
ADF intake $(\mathrm{kg} / \mathrm{d})$ & 5.21 & 0.02 \\
NFC intake $(\mathrm{kg} / \mathrm{d})$ & 7.64 & 0.04 \\
\hline
\end{tabular}

nutrients and produced more milk although the concentration of milk fat was reduced. This is somewhat different from previous results. For instance, increasing concentrate acidogenicity was negatively related to dry matter intake (Wadhwa et al., 2001b) and milk yield (Dewhurst et al., 2001), with variable effects on milk composition. The PAPV of TMR used in the experimental farms ranged from 5 to 15 ; therefore, the PAPV was not high enough to yield a negative impact on production traits. Welch et al. (1969) indicated that NDF is the nutritional

Table 6. Pearson's correlations among parameters from 744 multiparous lactating Holstein cows

\begin{tabular}{|c|c|c|c|c|c|c|c|c|c|c|c|c|}
\hline & Parity & DIM & MY & FCM & Mf & $\mathrm{Mp}$ & PAPV & DMin & $\mathrm{NE}_{\mathrm{L}}$ in & Mpin & NDFin & NFCin \\
\hline Parity & 1.00 & -0.10 & 0.09 & 0.08 & -0.07 & -0.15 & 0.07 & -0.04 & -0.01 & -0.02 & -0.12 & 0.01 \\
\hline DIM & -0.10 & 1.00 & -0.62 & -0.56 & 0.40 & 0.67 & -0.59 & -0.56 & -0.57 & -0.57 & -0.39 & -0.58 \\
\hline MY & 0.09 & -0.62 & 1.00 & 0.94 & -0.36 & -0.57 & 0.91 & 0.88 & 0.90 & 0.89 & 0.62 & 0.90 \\
\hline FCM & 0.08 & -0.56 & 0.94 & 1.00 & -0.05 & -0.47 & 0.83 & 0.82 & 0.85 & 0.83 & 0.57 & 0.83 \\
\hline Mf & -0.07 & 0.40 & -0.36 & -0.05 & 1.00 & 0.51 & -0.42 & -0.37 & -0.35 & -0.38 & -0.28 & -0.41 \\
\hline $\mathrm{Mp}$ & -0.15 & 0.67 & -0.57 & -0.47 & 0.51 & 1.00 & -0.52 & -0.53 & -0.55 & -0.56 & -0.35 & -0.55 \\
\hline PAPV & 0.07 & -0.59 & 0.91 & 0.83 & -0.42 & -0.52 & 1.00 & 0.89 & 0.90 & 0.91 & 0.61 & 0.96 \\
\hline DMin & -0.04 & -0.56 & 0.88 & 0.82 & -0.37 & -0.53 & 0.89 & 1.00 & 0.99 & 0.99 & 0.86 & 0.97 \\
\hline $\mathrm{NE}_{\mathrm{L}}$ in & -0.01 & -0.57 & 0.90 & 0.85 & -0.35 & -0.55 & 0.90 & 0.99 & 1.00 & 0.99 & 0.79 & 0.98 \\
\hline Mpin & -0.02 & -0.57 & 0.89 & 0.83 & -0.38 & -0.56 & 0.91 & 0.99 & 0.99 & 1.00 & 0.79 & 0.99 \\
\hline NDFin & -0.12 & -0.39 & 0.62 & 0.57 & -0.28 & -0.35 & 0.61 & 0.86 & 0.79 & 0.79 & 1.00 & 0.74 \\
\hline NFCin & 0.01 & -0.58 & 0.90 & 0.83 & -0.41 & -0.55 & 0.96 & 0.97 & 0.98 & 0.99 & 0.74 & 1.00 \\
\hline
\end{tabular}

DIM = Days in milk, MY = Milk yield, FCM = Fat corrected milk, Mf = Milk fat, Mp = Milk protein, PAPV = Potential acid production value, $\mathrm{DMin}=$ Dry matter intake, $\mathrm{NE}_{\mathrm{L}}$ in $=\mathrm{NE}_{\mathrm{L}}$ intake, Mpin $=$ Metabolizable protein intake, NDFin $=$ NDF intake, $\mathrm{NFCin}=\mathrm{NFC}$ intake . 


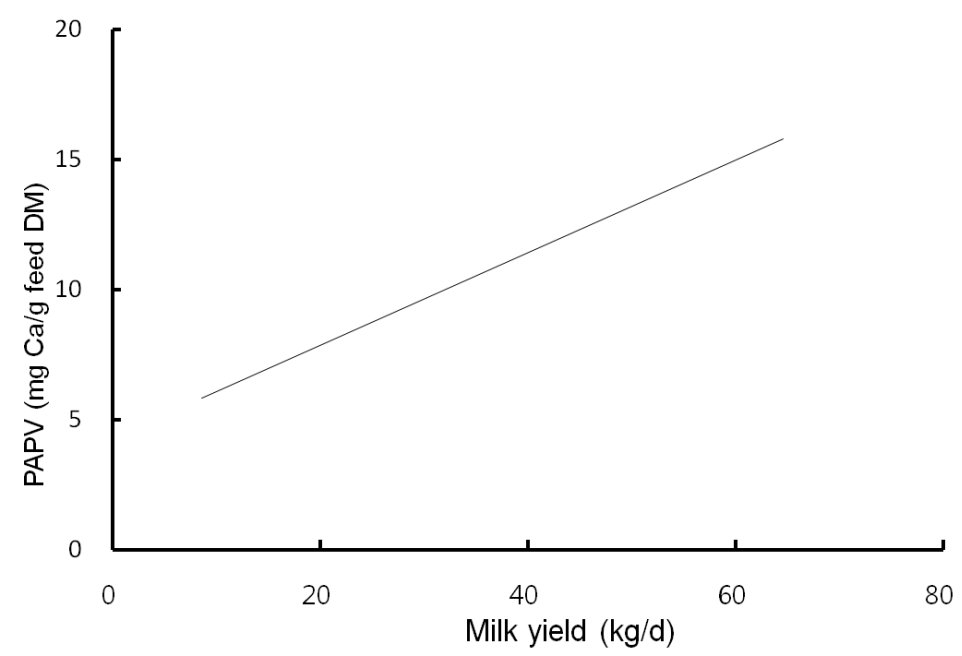

Figure 1. The relationship between dietary potential acid production value (mg Ca/g feed DM) and milk yield (kg/d) from 744 multiparous lactating Holstein cows.

component of roughage that is connected with chewing activity, which is now frequently suggested in the literature as minutes per kilogram of NDF intake. However, chemical benefits of fiber alone are not suitable for optimal diets of high producing dairy cows due to the variation of fiber effectiveness in stimulating chewing, resulting from differences in particle length. Nocek et al. (1988) reported that a proper ratio of non-structural carbohydrate to NDF be used to formulate diets to maximize milk yield. Poore et al. (1991) insisted that the optimal ratio of forage NDF to ruminally degraded starch be maintained $\geq 1: 1$ (wt/wt) to prevent a decrease in milk fat $(\%)$ when high NDF forage replaced low NDF forage. In general, structural NDF is important for cud chewing and good rumen health, and chemical NDF provides energy for milk and milk fat production. Some nutritional factors could be considered to influence fiber balance in dairy cow diets. Many nutritionists have used forage NDF as a guideline for optimal rumen health and DM intake. The NDF fraction, generally a low rate of digestion, is considered the primary dietary constituent related with rumen fill effect (NRC, 2001). Mertens (1994) reported that ruminal expansion limits DM intake due to the low flow capacity of undigested feed residues; forage NDF intake and fecal output are increased through pelleted high-fiber forages. Optimal forage NDF should be $20 \%$ to $21 \%$ of dry matter in diets. Total NDF should be increased when feeding less than $20 \%$ forage NDF. In this study, the level of forage NDF was about $13.7 \%$ in diets and lower than the optimal level. However, the level of total NDF intake in the diets was not low. The minimum level of structural fiber (NDF) was required to prevent acidosis and other metabolic upsets of the rumen connected with a lack of buffering capacity due to low structural fiber in diets. A negative correlation between dietary PAPV and milk protein was noticed, although the relation was not significant in the present study. Dewhurst et al. (2001) reported that milk protein concentration was not influenced by concentrate type when using corn silage as a roughage source but tended to be higher when high acid load concentrates were fed with grass silage. However, the relationship was not sound, which indicates that milk protein did not fluctuate to a great extent based on diet. Also, the present results showed a negative relationship between PAPV and milk fat content. Researchers (Clark et al., 1993; Depies et al., 1995; Armentano et al., 1997) suggested previously that milk fat response be used to determine NDF effectiveness for nonforage fiber sources as a method of uniting these complex interactions. However, there might be limited application for this technique because effectiveness values have not been repeatable across different types of diets (Clark et al., 1993). As milk yield increases, dietary PAPV also increased (Figure 1), which was reflected in an increased energy requirement for higher milk production. Our result also showed that PAPV for dairy TMR greater than 13.5 did not increase milk yield.

In conclusion, PAPV, although variable, can provide information on acid production capacity of feedstuffs and may be applied to ration formulation for ruminant animals.

\section{ACKNOWLEDGEMENTS}

This work was financially supported by the Rural Development Administration, MAF, Korea. E. T. Kim was supported by a scholarship from the BK21 Program, the Ministry of Education, Science and Technology, Korea.

\section{REFERENCES}

Allen, M. S. 1997. Relationship between fermentation acid 
production in the rumen and the requirement for physically effective fiber. J. Dairy Sci. 80:1447-1462.

AOAC. 1990. Official methods of analysis. 14th ed. Assoc. Offic. Anal. Chem., Washington DC, USA.

Armentano, L. E. and M. Pereira. 1997. Measuring effectiveness of fiber by animal response trials. J. Dairy Sci. 80:1416-1425.

Ash, R. W. 1959. Inhibition and excitation of reticulo-rumen contractions following the introduction of acids into the rumen and abomasum. J. Physiol. 147:58-73.

Choi, Y. J., S. S. Lee, J. Y. Song, N. J. Choi, H. G. Sung, S. G. Yun and J. K. Ha. 2003. Effects of dietry acidogenicity values on rumen fermentation characteristics and nutrients digestibility. Asian-Aust. J. Anim. Sci. 16:1625-1633.

Clark, P. W. and L. E. Armentano. 1993. Effectiveness of neutral detergent fiber in whole cottonseed and dried distillers grains compared with alfalfa haylage. J. Dairy Sci. 76:2644-2650.

Clark, P. W. and L. E. Armentano. 1997. Replacement of alfalfa NDF with a combination of nonforage fiber sources. J. Dairy Sci. 80:675-680.

Crawford, R. J. Jr., B. J. Shriver, G. A. Varga and W. H. Hoover. 1983. Buffer requirements for maintenance of $\mathrm{pH}$ during fermentation of individual feeds in continuous cultures. J. Dairy Sci. 66:1881-1890.

Depies, K. K. and L. E. Armentano. 1995. Partial replacement of alfalfa fiber with fiber from ground corn cobs or wheat middlings. J. Dairy Sci. 78:1328-1335.

Dewhurst, R. J., D. Wadhwa, L. P. Borgida and W. J. Fisher. 2001. Rumen acid production from dairy feeds. 1. Effects on feed intake and milk production of dairy cows offered grass or corn silages. J. Dairy Sci. 84:2721-2729.

Dunlop, R. H. 1972. Pathogenisis of ruminant lactic acidosis. Adv. Vet. Sci. Comp. Med. 259-302.

Fondevilla, M., C. Castrillo, J. A. Guada and J. Balcells. 1994 Effect of ammonia treatment and carbohydrate supplementation of barley straw on rumen liquid characteristics and substrate degradation by sheep. Anim. Feed Sci. Technol. 50:137-155.

Jasaitis, D. K., J. E. Wohlt and J. L. Evans. 1987. Influence of feed ion content on buffering capacity of ruminant feedstuffs in vitro. J. Dairy Sci. 70:1391-1403.

Lee, H. J., S. C. Lee, J. D. Kim, Y. G. Oh, B. K. Kim, C. W. Kim and K. J. Kim. 2003. Methane production potential of feed ingredients as measured by in vitro gas test. Asian-Aust. J. Anim. Sci. 16:1143-1150.

Mertens, D. R. 1994. Regulation of forage intake. Page 450 in Forage Quality, Evaluation, and Utilization (Ed. G. C. Fehey, Jr.). Am. Soc. Agron., Madison, WI, USA.
Nocek, J. E. and J. B. Russell. 1988. Protein and energy as an integrated system. Relationship of ruminal protein and carbohydrate availability to microbial synthesis and milk production. J. Dairy Sci. 71:2070-2107.

NRC. 2001. Nutrient requirements of dairy cattle, 7th ed. National Academy Press, Washington, DC, USA.

Oliveira, L. A., C. Jean-Blain, S. Komisarczuk-Bony, A. Durix and C. Durier. 1997. Microbial thiamin metabolism in the rumen simulating fermenter (RUSITEC): the effect of acidogenic conditions, a high sulfur level and added thiamin. Br. J. Nutr. 78:599-613.

Playne, M. L. and P. McDonald. 1966. The buffering constituents of herbage and of silage. J. Sci. Food Agric. 17:264-268.

Poore, M. H., J. A. Moore, R. S. Swingle, T. P. Eck and W. H. Brown. 1991. Wheat straw or alfalfa hay in diets with $30 \%$ neutral detergent fiber for lactating Holstein cows. J. Dairy Sci. 74:3152-3159.

Russell, J. B. and J. L. Rychlik. 2001. Factors that alter rumen microbial ecology. Science 11:1119-1122.

SAS Institute, Inc. 1995. SAS user's guide: Statistics. SAS Inst. Inc. Cary, NC.

Smith, W. R., I. Yu and R. E. Hungate. 1973. Factors affecting celluloysis by Rminococcus albus. J. Bacteriol. 114:729-737.

Song, J. Y. 2005. Standardization of feed acidogenicity value (AV) and effect of different $\mathrm{AV}$ diets on rumen fermentation characteristics. (A Thesis For the Degree of Master of Science)

Van Soest, P. J. and J. B. Robertson. 1985. Analysis of forages and fibrous foods. AS 613 Manual, Dep. Anim. Sci., Cornell Univ., Ithaca, NY, USA.

Van Soest, P. J., J. B. Robertson and B. A. Lewis. 1991. Methods for dietary fiber, neutral detergent fiber, and nonstarch polysaccharides in relation to animal nutrition. J. Dairy Sci. 74:3583-3597.

Van Soest, P. J. 1994. Nutritional ecology of the ruminant, Second Edition. Cornell University Press, Ithaca, New York, USA.

Wadhwa, D., L. P. Borgida, M. S. Dhanoa and R. J. Dewhurst. 2001b. Rumen acid production from dairy feeds. 2. Effects of diets based on corn silage on feed intake and milk yield. J. Dairy Sci. 84:2730-2737.

Wadhwa, D., N. F. Beck, L. P. Borgida, M. S. Dhanoa and R. J. Dewhurst. 2001a. Development of a simple in vitro assay for estimating net rumen acid load from diet ingredients. J. Dairy Sci. 84:1109-1117.

Welch, J. G. and A. M. Smith. 1969. Influence of forage quality on rumination time in sheep. J. Anim. Sci. 28:813-818. 